\title{
Portugal's Estado Novo Regime and Apartheid South Africa: two dictatorships and their diplomatic exchanges
}

\section{Luís Sargento Freitas*}

* Department of Social Sciences and Philosophy, University of Jyväskylä, Finland; luisnsaf@gmail.com

\section{Resumo}

Este estudo analisa a política externa e as trocas diplomáticas do regime do Estado Novo Português e o regime do Apartheid na África do Sul. De modo a investigar este tópico, foi feita uma pesquisa nos Arquivos da Torre do Tombo e no Ministério dos Negócios Estrangeiros de Portugal. Depois de uma cuidada seleção dos mais importantes documentos que servem aos propósitos deste estudo, realizámos uma revisão da literatura da especialidade, principalmente na história de Portugal e relações internacionais. As mais importantes razões para a proximidade destas duas políticas externas principalmente após a Segunda Guerra Mundial são debatidas, quer militarmente, economicamente ou politicamente. O intervalo temporal desta investigação é desde 1945 até 1974, no entanto, muitos eventos que ocorreram antes e após estas datas serão também escrutinados.

Palavras-chave: África do Sul; Apartheid; diplomacia; Estado Novo; Portugal; relações internacionais

\begin{abstract}
This paper intends to analyze the foreign policies and diplomatic exchanges of Portugal's Estado Novo Regime and Apartheid South Africa. In order to fully research these subjects, a search was made in the Portuguese National Records (Torre do Tombo) and the Portuguese Ministry of Foreign Affairs. After a careful selection of the most important documents that served the purposes of this study, we performed a literature review of the subjects at hand, mainly in (Portuguese) history and international relations. The most important reasons for the proximity of these two foreign policies after World War II are extensively debated, whether militarily, economically and politically. The time-span of this research is from 1945 until 1974, however, several events that occurred before and after these dates shall also be scrutinized.
\end{abstract}

Keywords: Apartheid; diplomacy; Estado Novo; international relations; Portugal; South Africa 


\section{Introduction}

Diplomatic relations between Portugal and South Africa were started in February 1886 when diplomatic mail was exchanged between the two countries discussing the arrival of a South African minister that would reside in Lisbon and would thus serve as an ambassador, even though he was only referred to as a minister. Later, on the $1^{\text {st }}$ of April of 1923, a "Modus Vivendi" was established by the two governments in order to organize and legislate labor policies, more specifically, Portuguese labor that could be recruited by South African officials. This legislation would be further adapted and modified on the $11^{\text {th }}$ of September of 1928 in Pretoria ${ }^{[1]}$.

The fields of study in which this paper can be included are contemporary history, history of international relations, political and diplomatic history, comparative studies, studies on dictatorships and authoritarian governments and regimes, and (Portuguese) foreign policy studies. Even though Portuguese and South African foreign policy of these years shall be debated, this paper is better included in Portuguese contemporary (political) history as mostly Portuguese documents from the Portuguese National Records (Torre do Tombo) and the Portuguese Ministry of Foreign Affairs are analyzed. However, this study is also relevant for South African scholars as many moments in South African history are debated.

Portuguese political science and history literature is vast when it comes to subjects such as Greek, Roman, medieval, modern and contemporary (political) history, foreign policy, the study of authoritarian regimes, and many other subjects. However, after a careful review of literature, we discovered that the political history between these two countries and its different regimes had not been debated to a great extent.

\section{Review of literature and post-World War II Portuguese-South African relations}

Important Portuguese scholars on history and foreign policy studies are, for example, Fernando Rosas (1988), Nuno Severiano Teixeira (2005, 2010), Luís Reis Torgal (2009) or José Mattoso (1998). These authors tend to debate countries, states, governments and regimes that Portuguese governments and regimes perceived as of great importance to its political environment. Such examples are Brazil, France, Angola, England, the United States, India among many others, in other words, the countries that mostly affected Portuguese foreign policy in Europe or throughout the world. South Africa was then a case that was not of direct importance to Portuguese politics, but one that was geographically and politically connected due to its proximity with Mozambique, and to some extent Angola, which were former Portuguese colonies. This political proximity between Portugal, Angola, and Mozambique and other Portuguese speaking countries continues until today in democratic times (after the

1. This information is available at the diplomatic portal of the Portuguese Ministry of Foreign Affairs: [Accessed on the 09-08-2018]; URL: <https://www.portaldiplomatico.mne.gov.pt/relacoesbilaterais/ paises-geral/africa-do-sul>. 
fall of the Estado Novo Regime in Portugal in 1974 and the end of the Apartheid regime in South Africa in 1994).

It is possible to contend that the Estado Novo regime in Portugal was a dictatorship of fascist influence that lasted for about 41 years (1933-1974). However, as Torgal (2009) states there is still a great debate and dissensus on the most appropriate categorization for this Portuguese political regime. As Torgal states, the academic world is divided between the acceptance of this regime as a de facto fascist regime or merely a corporatist regime of catholic influence. It is the contention of this paper that, although one can consider this regime as a fascist one, (as it had many of the state mechanisms as the Italian or German types of fascism) this dictatorship is of a sui generis type, that had clear differences to the Apartheid regime in South Africa. Differences between these two dictatorships will be stated in the coming pages.

During this time (1933-1974), the Estado Novo regime was able to maintain a legal neutrality in the Second World War, join the European Free Trade Alliance (EFTA) and the North Atlantic Treaty Organization (NATO) as a founding member-state while seeking to maintain a vast colonial empire in the continents of Africa (Angola, Mozambique, Cape Verde, São Tomé e Príncipe, Guiné-Bissau), and Asia (in parts of India such as Goa, Damão, Diu ${ }^{[2]}$, Macau - now part of China and East Timor). However, in the 1960's, with the ever-growing sentiment of desire for independence in African countries and anti-colonial feeling due not only to the spread of Communism but also due to American influence, a war broke out in all of the former Portuguese colonies in Africa. This was to be known as the "Colonial War" or "Guerra Colonial” (1961-1974).

Anti-colonial feeling was growing around the world ${ }^{[3]}$, however, opposite movements also existed and countries whose governments' foreign policies were against independence movements tended to cooperate. That was the case of countries such as Portugal, South Africa, Rhodesia (modern-day Zimbabwe) or others.

If diplomatic relations only existed between Portugal and the government of South Africa, ever since the XIX century, Portugal had a long history with this country/territory. Portuguese sailors were the first to cross the Cape of Good Hope in the XVI century while using Robben Island ${ }^{[4]}$ as a stopping point. The goal of these sailors was to reach India by sea, around Africa, as it was impossible to do it by land due to the growth of Islamic followers in the areas around the Mediterranean. These

2. Or, for example, Malaca in contemporary Malaysia, which was then overtaken by Dutch and later British rule before gaining independence. The Portuguese were also the first Europeans to reach Japan.

3. Not only were movements in Africa and Asia growing, that contested colonial rule, several countries and governments in Europe were also empowering African liberation movements such as Norway, Sweden, Denmark and Finland.

4. Robben Island, which is next to Cape Town was a stopping point for many European sailors, which was later transformed into a prison which was where Nelson Mandela spent most of his imprisonment before his liberation in 1990. 
Muslim groups controlled most of the land, having later given rise to the Ottoman Empire that was also increasingly dominant in this geography.

With this intent to reach India by Portuguese sailors, the coast of Africa was explored (as was also America and Brazil that fell under Portuguese control after the Treaty of Tordesilhas with the Spanish Crown), land settlements and forts were built, and, with time, a multi-continental empire was built that used Portuguese and indigenous labor and also slavery as its workforce. Human rights or freedom of speech did not exist.

After Brazil's independence in 1822, the succeeding Portuguese governments (monarchical and as a Republic after 1910) gave African colonies greater attention. The Estado Novo regime continued this philosophy which was based on an alliance with England (the oldest alliance in the world formed in 1386 by the Treaty of Windsor) to protect itself from any European invasion while putting a great part of its resources in its empire, particularly in Africa.

The independence movements in its former African colonies were then a threat to its traditional foreign policy. These independence movements were also viewed as a threat in South Africa during the Apartheid regime as a white minority rule was in government in both South Africa and Rhodesia (contemporary Zimbabwe).

The research question of this paper is thus: Why did these two regimes (Estado Novo in Portugal and Apartheid South Africa) need to establish greater diplomatic ties in the years following World War II and during the Cold War until 1974?

This study will at first distinguish between the ideologies of these regimes, their similarities and differences and then study the documents found in Portuguese records which will show the Portuguese officials' views and interpretations of the time regarding the developments in the extreme South of the African continent. Several aspects of each government's foreign policy will be debated whether in terms of military aid, geopolitical concerns, trade, energy policy, and other issues.

The Estado Novo's regime in Portugal was a particular kind of fascism with similarities but also differences to those of Franco in Spain, Mussolini in Italy and even Hitler in Germany. It was a secular state albeit having a strong relationship with Catholicism and even the Vatican and it did not allow freedom of press or voting rights for women. It also fought communist groups in Portugal and abroad as communism was forbidden in its territories ${ }^{[5]}$. This regime had always assumed that it had developed a different kind of colonialism, different from the British, French or Dutch, one of mixture between its peoples, as Portuguese citizens from the mainland were more equal to citizens of African or Asian origin (even though that was not the case in everyday life). African-born citizens could enlist in the Portuguese army. They could, in theory, have political and governmental positions, even though that never

5. Before the Estado Novo regime, Portugal had already cut ties with the Soviet Union in 1918 right after the end of World War I. It would also end diplomatic ties with Poland and other communist countries in 1945 after the inclusion of Poland in the Soviet sphere. 
happened. Portugal was thus understood by its leaders of the time as a multicontinental state and country ran from its center, the city of Lisbon (Torgal, 2009).

Apartheid South Africa was a different kind of regime. It was not a fascist regime as it debated many of its political issues in a quasi-parliamentary manner, although its parliament did not have members of African origin. It did not have a Duce figure. Freedom of speech was not greatly permitted and the death penalty was enforced for crimes of higher nature. However, the influences of Dutch and English colonialism with a stronger emphasis in the separation between European descendants and African natives, gradually gave to rise to the forced mobilization of different ethnic groups and a separation of populations. With this in mind, one can see that there were nevertheless some similarities between fascist governments in Europe, such as the Portuguese variant, and this particular regime in South Africa.

Even though, diplomatic exchanges had existed between Portugal and South Africa for several decades, some of the oldest available documents which are accessible in the Portuguese national records date back from the 1930s to the years before the outbreak of World War II.

The Security of the Union requires an understanding with the Portuguese Government that assures a coastal defense and the invulnerability of its industrial mining centers. It wouldn't be a surprise that the port of Lourenço Marques [modern-day Maputo] would play an important role in the plans of the South African state given its strategic importance for the defense of the Rand. ${ }^{[6]}$

Portugal remained neutral (at least on paper) through World War II due to various reasons. Its ancient alliance with England and close economic ties with the United Kingdom remained. However, the political and ideological proximity between the Portuguese Estado Novo and the Italian and German Fascisms prevented a declaration of war from Portugal towards these two states ${ }^{[7]}$.

The German population or German descendants in South Africa which might or might not have had affiliations with the German Nazi government also posed a threat and a concern for the South African government of the time (which later, and due to other reasons, led to the declaration of war of South Africa to Nazi Germany). At the same time, commercial ties between Mozambique (which was under Portuguese colonial rule) and South Africa were multiple and involved many commodities. In 1938, the South African economy was improving which allowed for an increase in trade. Political relations between these two governments were thus very important and involved areas such as defense, economic policies, and infrastructure development.

6. Torre do Tombo, 1938, Reference: Aos/co/NE-UG pp. 338-370, pg. 340, Lisbon, Portugal (translated from Portuguese by the author).

7. It is important to remember that Portugal sided with England and France and the Triple Entente in World War I and after the Russian Communist Revolution, Portugal cut off diplomatic ties with the Soviet Union. 
The creation of a consulate of the Soviet Union in South Africa around 1943 led to some of the first revolts against the South African Apartheid government in areas such as Midrand and Pretoria. These disorders were eventually controlled by force and the use of armored cars. However, it was due to this event, that communist propaganda greatly developed in South Africa, at first, without much opposition as they were relatively small and localized occurrences. Greater anti-revolt and defensive movements could nevertheless have been necessary in the future (and they were indeed imperative as we shall see). The opening of this consulate was thus a turning moment in South African politics even though this did not appear to be a big issue for the South African government of the time.

The western and eastern coast of South Africa was, during the Cold War, an important geostrategic area as an eventual fall of the Persian Gulf to the communist side with the intent of greater control of oil supplies by communist powers would make the Cape of Good Hope an important point of passage to the orient connecting the Atlantic and Indian Oceans.

Some years later, the support of the Soviet Union, China and even Scandinavian countries to revolutionary movements all over Africa was the materialization of this interest in African affairs as they were trying to win the favor of new or upcoming African governments and movements which were appearing all over this continent.

The United States, on the other hand, sought to develop a mixed foreign policy by supporting independentist movements with private investment while, at the same time, not allowing the expansion of communism. The fact that the United States was heavily involved in East Asia firstly in the Korean war and later in the Vietnam war also put African problems on a secondary level of importance. The USA did, however, distance itself from the segregationist policies of Apartheid South Africa in its society, universities and labor force. The United States were thus also somewhat distrustful of Portuguese colonial presence in Africa while, at the same time, fearing communist diffusion in Angola, Mozambique or other areas. They therefore also partially accepted the Portuguese point of view but did not have great hopes in a Portuguese victory due to the difficulty in obtaining a full victory in such difficult geographical conditions, and also due to the international situation that would increasingly isolate Portugal ${ }^{[8]}$. President Nixon, for example, (in office from 1969 until 1974) went to the celebration of Ghana's independence and had already created four new consulates in Africa and a special section in the State Department for African Affairs. The fear of repeated take-overs by communist movements in Africa, were a constant concern for the USA ever since the communist revolt in China under Mao Zedong. Therefore, a battle for African friendships by Communist, Capitalist and even neutral countries emerged ${ }^{[9]}$.

8. This information was obtained in the documents analyzed for this study (annexes 1-18).

9. Discussions between Portuguese and South African officials written in the documents that were researched for this paper (see annexes) state that Cuban influence was also present in Southern Africa although its significance on the ground was not greatly feared by these two governments. 
The international situation in Africa and the world, in the 1950s and 1960s was increasingly opposed to European colonial presence in Africa with the United Kingdom being one the defenders of such policies. It became increasingly harder for the European post-war states to effectively manage multi-continental empires; therefore, it was believed that the 1950s, 60s and 70s would be a time when African governments would be led by native Africans. However, governments such as the Portuguese Estado Novo and Apartheid South Africa were vehemently opposed to the end of European rule in Africa or, in the case of South Africa, to the end of an Apartheid government led by European "white" descendants or a "white minority" that had existed since 1948.

Apartheid South Africa and Portugal's Estado Novo were increasingly ostracized by the international community and also inside its own territory ${ }^{[10]}$ which was also the reason for Salazar's ${ }^{[11]}$ expression "orgulhosamente sós", in other words, "proudly alone". The Estado Novo regime, on the other hand, stated that all the countries that criticized Portugal's involvement and presence in Africa did so due to a fear of Soviet aggression or merely to appease it. The Communist Party in Portugal was, at this time, an underground and illegal movement that was one of the first to openly oppose Salazar's government using protests, attacks, and organized crime while opposing Portuguese presence in Africa.

The reason for the close partnership between these two governments is very evident. Both foreign policies were intertwined and maintained similar objectives which involved preventing independentist movements from gaining greater support among African populations mostly in South Africa, Angola, and Mozambique but also in nearby regions such as Rhodesia (contemporary Zimbabwe), Bechuanaland (contemporary Botswana) and Northern Rhodesia (contemporary Zambia). As some of these regions gained independence one after the other with the consent of the British, American or other governments, it appeared as almost inevitable that such movements would affect the former Portuguese colonies and South Africa as well. The attack by MPLA ${ }^{[12]}$ combatants in Angola in 1961 appeared to be the start of this anti-colonial process. Maintaining colonial Portuguese rule in Angola and Mozambique which were neighboring regions to South Africa was thus an important aspect of foreign policy for the Apartheid South African government.

10. The Calvinist Church of South Africa was also anti-Apartheid and opposed ethnical divisions and hierarchies.

11. António de Oliveira Salazar was at first a Finance Minister and later the Prime Minister and effectively the main authoritarian leader of Portugal's Estado Novo regime.

12. Movimento Popular de Libertação de Angola or, in other words, People's Movement for the Liberation of Angola. Other movements in Angola were, for example, UNITA - União Nacional para a Independência Total de Angola, or, The National Union for the Total Independence of Angola. In Mozambique, the most important anti-colonial movements were FRELIMO (Frente de Libertação de Moçambique or Mozambique Liberation Front), whose most important representatives were Marcelino dos Santos who made numerous trips to Scandinavia and other African countries seeking financial and military support for FRELIMO, and Joaquim Chissano. 
These isolationist policies only grew as time passed. On the $12^{\text {th }}$ of November, 1965, there was an oil embargo and the breaking of economic relations with Southern Rhodesia (contemporary Zimbabwe) by a United Nations Security Council resolution.

Some years later in 1966, as the documents analyzed for this study state, there were fears of a possible British attack to South Africa and Mozambique which was a reason for concern for both Portuguese and South African former governments. South Africa was the country with the greatest military resources ${ }^{[13]}$ in the area which would probably have prevented the success of such attacks, however, the mentioning of such possible military movements by high political representatives paints a deeply isolationist policy by Apartheid South Africa and colonial Mozambique. The British military and navy did however have orders not to shoot any boats in the area even if they were breaking maritime rules in order not to create further political distress with South Africa ${ }^{[14]}$. The British position had similarities with the American one, favoring an ambivalent policy as it opposed most policies by Apartheid South Africa but also seemed not to overly support native Africans with the fear of the spread of Communism while knowing that the South African economy was possibly the most relevant one in Southern Africa. The English would then use intimidation tactics but would not start a war.

Apartheid South Africa and Portugal's Estado Novo thus had close foreign policies but there was little coordination between the military forces of both governments. However, in the hypothetical case of an invasion of South Africa through a pincer-movement, through Portuguese colonial territory, and the incapacity of Portugal's military to prevent it, South Africa would be forced to enter Angola or Mozambique to defend its regime ${ }^{[15]}$.

I started by saying that I wished to talk about a few topics that worried me that had or might have had an impact in the relations between both countries [Portugal and South Africa]. These relations were excellent, and they should continue to be, as these two countries have an absolute necessity of one another. We wished for nothing else and would do everything to keep the strong friendship between our two governments. ${ }^{[16]}$

13. Apartheid South Africa had the Permanent Force, the Coast Garrison Force, and the Active Citizen Force were the main divisions of this country's defense forces as was stated by Sir Pierre van Ryneveld, an important South African military and commander of the South African Air Force.

14. Such fact was referred to Portuguese authorities by Pieter Willem Botha who was South Africa's Minister of Defense at this time, later the Prime Minister and afterwards the 6th State President of South Africa.

15. The South African government and economy of the time had relatively advanced industries which allowed to manufacture weapons, bullets, armored cars and other equipment (they also possessed many Dakota aerial combat-fighters) which was also one more reason that justifies the duration of this Apartheid government until 1994.

16. This paragraphed was translated from Portuguese by the author and is available at: Torre do Tombo, 1963, "Conversa do Ministro dos Negócios Estrangeiros, Alberto M. Franco Nogueira com o Embaixador da República da África do Sul”, Reference code: PT/TT/AOS/D-J/8/20/22, Lisbon, Portugal, pp. 118. [Dis- 
This strong friendship did not just involve military and foreign policy collusion of interests, it also extended to the economic ${ }^{[17]}$ and infrastructural areas. The construction of the Cahora Bassa dam in Mozambique was a project that involved many resources, several diplomats from both governments, and an extensive contract that was signed on the $19^{\text {th }}$ of September, 1969, in Lisbon, and was entitled Draft Agreement between the Governments of the Republic of South Africa and of Portugal concerning the supply of electric power.

Transmission lines were to be built by both sides and to be exploited for mutual benefit among private and public entities who would be responsible for the producing, the exchange, and transmission of energy. The contract would be set as to provide welfare to the populations, and a sharing of electric power, where South Africa would import and purchase electric energy on certain specified conditions.

South Africa did not possess, at this time, the capabilities for the production of nuclear plants and it did not have enriched uranium. The Western Cape was an area that had already started to require greater energy resources from various locations (and the use and availability of desalinated water) as it was distanced from the biggest carbon deposits. Hydro-electric projects were either being built or were at the project phase. The South African government did then need to establish this Agreement with Portugal as it was mutually beneficial. Portugal and the area of Mozambique would see this specific kind of exports rise, its economy would in theory grow as would the political relations with South Africa, and both governments' interdependence. This fact was one of the reasons why FRELIMO planned and organized several attacks on this dam and its electric connections ${ }^{[18]}$. This dam would come to symbolize and be used by the Estado Novo's propaganda abroad and indoors as its proof of commitment to economic growth in Africa and would at first be seen by FRELIMO as an infrastructure built solely for the purpose of the continuation of a "white" dominion in Southern Africa. However, after the 1974 revolution in Portugal, the first Mozambican governments would start to view this dam as a valuable economic asset in its post-colonial development but also as a weapon against the South African Apartheid government.

cussion between the Minister of Foreign Affairs, Alberto M. Franco Nogueira and the Ambassador of the Republic of South Africa].

17. Portugal would also export to South Africa commodities such as wood, coffee (from Angola), oil products, butane gas, cement, and bananas as the documents we analyzed had referred (see list of annexes). Other affairs related to Mozambique were also labor, the oil pipe of Lorenzo Marques (contemporary Maputo), natural gas from Mozambique, railway tariffs from the Transvaal miners. Regarding the Angolan territory the main concerns were the using of water from the Cunene river for irrigation purposes for the South African territory, capital investment, and the presence and habitation of about 300 South African citizens in Southern Angola who lived in isolation. As to Mozambique, the main debates were about the availability of the Lorenzo Marques' harbor and railways for South African boats and trains, and the management of aerial traffic. This information is available at: Torre do Tombo, reference code: AOS/CO/ UL-55; "Negociações com a África do Sul", pp. 1-98.

18. This Cabora Bassa dam would continue to be a factor for political tensions between democratic Portugal, Apartheid and democratic South Africa and post-colonial Mozambique. 
All of these economic and political issues regarding this dam must be viewed skeptically as the construction of this dam forced many people to relocate to different areas and several natural and agricultural areas were deprived from the Zambesi river waters. It was thus an infrastructure with a potential for economic development in the area but also a framework with great environmental adversity.

\section{Conclusion}

The research question of this paper was: Why did these two regimes (Estado Novo in Portugal and Apartheid South Africa) need to establish greater diplomatic ties in the years following the Second World War, and during the Cold War until 1974? After this analysis, the answers to this research question appear to be more evident.

Our study has brought to light the fact that, among other reasons, the opening of an embassy of the USSR in South Africa was an important factor that gave rise to many opposition movements in the 1950s during the governance of Apartheid South Africa.

The political situation in the world and in the African continent after World War II continuously led to the end of colonialism and European rule (or in the case of South Africa to the end of a government of European descendants) in several African and Asian states. The fact that the Portuguese Estado Novo government had colonial control of several African states such as Mozambique, Angola, Cape Verde, Guiné-Bissau, São Tomé e Príncipe and other regions in the Asian continent, and was a strong supporter for the continuation of such a system, coupled with the fact that Apartheid South Africa maintained a government in which no indigenous or communist opposition was tolerated, increasingly led to the growth in diplomatic ties between these two dictatorships.

These diplomatic ties were maintained in order for this same system to be maintained and received both partial support and condemnation from the main super powers of the time. The USA viewed Portugal's position as one that was partially positive as it was fighting communism but one that would not survive for long, given the political situation of the time and the almost inevitable end of colonialism. The United Kingdom's position had many similarities with the American perspective. The British often used fear tactics against the governments of Portugal and South Africa but never declared war against any of these governments.

These factors led to a greater proximity of both governments' foreign policies which were increasingly politically isolated from the world. Portugal and South Africa were two economies that had relatively stable growth from 1950 until 1974 and that allowed them to join efforts in fighting independentist movements in their own geopolitical space in the Portuguese colonial war. Although there was never an established alliance or pact between these two governments, they worked together on political, economic, militaristic, and infrastructural projects. Both dictatorial regimes perceived one another as crucial elements in the maintenance of the status-quo in Southern Africa. 
The Cahora-Bassa dam construction in Mozambique was perhaps one infrastructure project that most closely connected both regimes.

The end of the Estado Novo regime in 1974 due to the April Revolution isolated Apartheid South Africa to a greater extent abroad and in its own territory, and would later dictate its ending in 1994 revealing to the world individuals such as Nelson Mandela and Frederik Willem de Klerk who were Nobel Peace Prize winners in 1993.

This study approached a specific time and space between South Africa and Portugal's relations and foreign policies. Future studies might continue this research focusing on the political situation of Apartheid South Africa and Portugal after 1974 or after Portugal's joining of the European Economic Community, or also in the periods from 1994 until present times when Portugal is in the European Union and South Africa is under a democratic system of government. We, therefore, hope that this paper can be a positive addition to this type of multidisciplinary studies.

Data de receção:24/11/2018

Data de aprovação:15/05/2018

\section{References}

Mattoso, J. (1998). História de Portugal, O Estado Novo (1926-1974) Vol. 7. Lisboa: Editorial Estampa.

Rosas, F. (1988). O Salazarismo e Aliança Luso-Britânica. Estudos sobre a Política Externa do Estado Novo nos Anos 30 e 40. Lisboa: Editorial Fragmentos.

Teixeira, N. S. (2005). Entre África e a Europa: Política Externa Portuguesa, 1890-2000. In A. C. Pinto (coord.), Portugal Contemporâneo. Lisboa: D. Quixote, pp. 87-116.

Teixeira, N. S. (2010). Breve Ensaio sobre a Política Externa Portuguesa. Relações Internacionais, 28, 51-60.

Torgal, L. R. (2009). Estados Novos, Estado Novo. Coimbra: Imprensa Universidade de Coimbra.

\section{Documents analyzed in this study}

Torre do Tombo. (1972). Cópia de Carta do Almirante H.H. Biermann da República da África do Sul (Código de Referência: PT/TT/AMC/12-79/00015.2). Lisbon: Portugal.

Torre do Tombo. (1966). Conversa do Dr. Hall Themido com Hendrik Frensh Verwoerd, Primeiro Ministro da República da África do Sul (Código de Referência, PT/TT/AOS/ D-J/8/19/14). Lisbon: Portugal.

Torre do Tombo. (1966). Conversa do Ministro dos Negócios Estrangeiros, Alberto M. Franco Nogueira com o Embaixador Burger, Enviado Especial do Primeiro Ministro da África do Sul, Hendrik Frensh Verwoerd (Código de referência PT/TT/AOS/D-J/8/19/12) Lisbon: Portugal. 
Torre do Tombo. (1964). Realização de Missão de Investigação à África do Sul para averiguar da situação política deste país e da sua atitude em relação a Portugal com especial incidência em Angola e Moçambique [Código de referência PT/TT/AOS/D-J/6/11/6; 1 capilha, 67 f. (145-211)] Lisbon: Portugal.

Torre do Tombo. (1957). Correspondência relativa às seguintes legações e embaixadas de Portugal em Pretória, União da África do Sul [Código de referência: PT/TT/AOS/ D-J/6/10/00064; 1 capilha, 4 f. (744-747)] Lisbon: Portugal.

Torre do Tombo. (1949). Proposta da União Sul Africana de Conclusão de Pacto de Defesa da África com a participação de Portugal (Código de referência: PT/TT/AOS/ D-J/12/20/61) Lisbon: Portugal.

Torre do Tombo. (1960-1967). Correspondência de Alberto M. Franco Nogueira, J. J. Fouche, Ministro da Defesa da República da África do Sul, Hendrik Verwoerd, Primeiro Ministro, entre outros [Código de Referência: PT/TT/AOS/C/3/0001/00011, 1 capilha, $54 \mathrm{f}$. (48-101)] Lisbon: Portugal.

Torre do Tombo. (1959-1961). Henrique Caldeira Queirós, Embaixada de Portugal na África do Sul" [Código de Referência, PT/TT/AOS/B/19/00009, 1 capilha, 2 f. (495-608)] Lisbon: Portugal.

Torre do Tombo. (1954-1961). Abranches Pinto (General). Embaixada de Portugal em Pretória, África do Sul e em Londres, Inglaterra [Código de referência: PT/TT/AOS/B/19/00007 1 capilha, 44 f. (303-346)], Lisbon: Portugal.

Torre do Tombo. (1959-1961). Henrique Caldeira Queirós, Embaixada de Portugal na África do Sul [Código de referência: PT/TT/AOS/B/19/00009, 1 capilha, 2 f. (495-608)], Lisbon: Portugal.

Torre do Tombo. (1963). Política em África, situação de Portugal e da África do Sul (Código de Referência: PT/TT/AOS/D-N/25/36/7) Lisbon: Portugal.

Torre do Tombo. (1967). Delegação Portuguesa às Conversações com a África do Sul (Código de Referência: PT/TT/AOS/D-N/25/32/10) Lisbon: Portugal.

Torre do Tombo. (1960-1964). Negociações com a África do Sul (Código de Referência: PT/TT/ AOS/D-N/25/32/1) Lisbon: Portugal.

Torre do Tombo. (1959). União da África do Sul, Realização de Congresso da Sabra-South African Bureau of Racial Affairs (Código de Referência: PT/TT/AOS/D-N/25/13/3) Lisbon, Portugal.

Torre do Tombo. (1940). Compra pelo Banco de Portugal à Colónia de Moçambique de barras de ouro que a África do Sul diz vender a preço e favor (Código de Referência: PT/TT/ AOS/D-N/18/2/7) Lisbon: Portugal.

Torre do Tombo. (1963). Consequências da revisão da Convenção entre Portugal e a República da África do Sul, Moçambique (Código de Referência: PT/TT/AOS/D-J/8/21/7) Lisbon: Portugal.

Torre do Tombo. (1963). Conversa do Ministro dos Negócios Estrangeiros, Alberto M. Franco Nogueira com o Embaixador da República da África do Sul (Código de Referência: PT/ TT/AOS/D-J/8/20/22) Lisbon: Portugal.

Torre do Tombo. (1967). Visita a Portugal do Ministro da Defesa da República da África do Sul, Botha (Código de Referência: PT/TT/AOS/D-J/8/19/17) Lisbon: Portugal. 


\section{Sobre o autor}

Luís Sargento freitas é doutorado em Ciência Política pela Universidade de Jyväskylä na Finlândia (novembro 2018). Durante o doutoramento, além da Finlândia, viveu na África do Sul durante perto de dois anos como doutorando visitante na Universidade de Fort Hare. Trabalhou na Comissão Europeia e em vários projetos de investigação. Publica regularmente artigos sobre políticas europeias, políticas agroambientais, política externa e parlamentarização. Encontra-se a desenvolver as primeiras abordagens ao seu projeto de pós-doutoramento.

\section{About the author}

Luís SARgento Freitas PhD in Political Science from the University of Jyväskylä in Finland (November 2018). During his PhD, beyond Finland, he also lived in South Africa for almost two years as a visiting PhD student at the University of Fort Hare. He has also worked in the European Commission and in several research projects. He regularly publishes articles on European policies, agri-environmental policies, foreign policy, and parliamentarisation. Currently, he is developing the first approaches to his postdoctoral project. 